\title{
Chest compression with a higher level of pressure support ventilation: effects on secretion removal, hemodynamics, and respiratory mechanics in patients on mechanical ventilation*
}

\author{
Compressão torácica com incremento da pressão em ventilação com \\ pressão de suporte: efeitos na remoção de secreções, hemodinâmica e \\ mecânica pulmonar em pacientes em ventilação mecânica \\ Wagner da Silva Naue, Luiz Alberto Forgiarini Junior, \\ Alexandre Simões Dias, Silvia Regina Rios Vieira
}

\begin{abstract}
Objective: To determine the efficacy of chest compression accompanied by a $10-\mathrm{cmH}_{2} \mathrm{O}$ increase in baseline inspiratory pressure on pressure support ventilation, in comparison with that of aspiration alone, in removing secretions, normalizing hemodynamics, and improving respiratory mechanics in patients on mechanical ventilation. Methods: This was a randomized crossover clinical trial involving patients on mechanical ventilation for more than $48 \mathrm{~h}$ in the ICU of the Porto Alegre Hospital de Clínicas, in the city of Porto Alegre, Brazil. Patients were randomized to receive aspiration alone (control group) or compression accompanied by a $10-\mathrm{cmH}_{2} \mathrm{O}$ increase in baseline inspiratory pressure on pressure support ventilation (intervention group). We measured hemodynamic parameters, respiratory mechanics parameters, and the amount of secretions collected. Results: We included 34 patients. The mean age was $64.2 \pm 14.6$ years. In comparison with the control group, the intervention group showed a higher median amount of secretions collected ( $1.9 \mathrm{~g}$ vs. $2.3 \mathrm{~g} ; \mathrm{p}=0.004)$, a greater increase in mean expiratory tidal volume ( $16 \pm 69 \mathrm{~mL}$ vs. $56 \pm 69 \mathrm{~mL} ; \mathrm{p}=0.018)$, and a greater increase in mean dynamic compliance $\left(0.1 \pm 4.9 \mathrm{cmH}_{2} \mathrm{O}\right.$ vs. $\left.2.8 \pm 4.5 \mathrm{cmH}_{2} 0 ; \mathrm{p}=0.005\right)$. Conclusions: In this sample, chest compression accompanied by an increase in pressure support significantly increased the amount of secretions removed, the expiratory tidal volume, and dynamic compliance.
\end{abstract}

(ClinicalTrials.gov ldentifier:NCT01155648 [http://www.clinicaltrials.gov/])

Keywords: Physical therapy modalities; Respiration, Artificial; Intensive care units; Respiratory therapy.

\section{Resumo}

Objetivo: Determinar a eficácia da manobra de compressão torácica, associada ao acréscimo de $10 \mathrm{cmH}_{2} \mathrm{O} \mathrm{na}$ pressão inspiratória basal em modo ventilatório com pressão de suporte, em comparação com a da aspiração isolada, em relação a remoção de secreções, normalização da hemodinâmica e melhora da mecânica pulmonar em pacientes em ventilação mecânica. Métodos: Ensaio clínico randomizado cruzado incluindo pacientes em ventilação mecânica por mais de 48 h internados no CTl do Hospital de Clínicas de Porto Alegre, em Porto Alegre, RS. Os pacientes foram randomizados para receber aspiração isolada (grupo controle) ou compressão torácica associada ao acréscimo de $10 \mathrm{cmH}_{2} \mathrm{O}$ na pressão inspiratória basal em modo ventilatório com pressão de suporte (grupo intervenção). Foram mensurados parâmetros hemodinâmicos e de mecânica respiratória, assim como a quantidade de secreção aspirada. Resultados: Foram incluídos 34 pacientes. A idade média foi de 64,2 $\pm 14,6$ anos. Na comparação com o grupo controle, o grupo intervenção apresentou uma maior mediana da quantidade de secreção aspirada (1,9 g vs. 2,3 g; $\mathrm{p}=0,004)$, maior aumento da variação da média do volume corrente expirado (16 $\pm 69 \mathrm{~mL}$ vs. $56 \pm 69 \mathrm{~mL} ; \mathrm{p}=0,018)$ e maior aumento da variação da média da complacência dinâmica $\left(0,1 \pm 4,9 \mathrm{cmH}_{2} \mathrm{O}\right.$ vs. $\left.2,8 \pm 4,5 \mathrm{cmH}_{2} \mathrm{O} ; \mathrm{p}=0,005\right)$. Conclusões: Na amostra estudada, a compressão torácica associada ao aumento da pressão de suporte aumentou significativamente a quantidade de secreção aspirada, o volume corrente expirado e a complacência dinâmica.

(ClinicalTrials.gov ldentifier:NCT01155648 [http://www.clinicaltrials.gov/])

Descritores: Modalidades de fisioterapia; Respiração artificial; Unidades de terapia intensiva; Terapia respiratória.

\footnotetext{
*Study carried out at the Hospital de Clínicas de Porto Alegre - HCPA, Porto Alegre Hospital de Clínicas - Porto Alegre, Brazil. Correspondence to: Wagner da Silva Naue. Hospital de Clínicas de Porto Alegre, Centro de Tratamento Intensivo, Rua Ramiro Barcelos, 2350, CEP 90035-903, Porto Alegre, RS, Brasil.

Tel. 5551 3331-7639. E-mail: wnaue@yahoo.com.br

Financial support: This study received financial support from the Fundo de Incentivo à Pesquisa (FIPE, Research Incentive Fund) of the Porto Alegre Hospital de Clínicas.

Submitted: 16 June 2013. Accepted, after review: 9 December 2013.
} 


\section{Introduction}

Most ICU patients require invasive ventilatory support and are therefore subject not only to the benefits gained from the institution of that support, such as maintenance of gas exchange and decreased work of breathing, but also to the deleterious effects associated with it, such as the impairment of the mucociliary transport and mucociliary clearance mechanisms. ${ }^{(1,2)}$ This impairment, in turn, can lead to stasis of secretions in the airways and consequently result in bronchial obstruction, ${ }^{(3)}$ which, in the long term, can cause atelectasis and episodes of hypoxemia. In addition, accumulation of bronchial secretions favors the multiplication of microorganisms in unventilated areas, leading to the establishment of respiratory infections, such as ventilator-associated pneumonia. ${ }^{(4-6)}$

Some physiotherapy techniques aim to enhance mucociliary clearance and thus prevent bronchial obstruction caused by accumulation of secretions. Chief among these techniques is manual expiratory passive therapy, which is defined as compression of the patient's chest during the expiratory phase with the aim of accelerating expiratory flow and moving secretions from peripheral to central airways, thereby facilitating their expectoration. ${ }^{(7,8)}$

The technique of chest compression alone is not always efficient. This is because patients on mechanical ventilation (MV) have impaired mucociliary clearance, which, combined with reduced expiratory flow, results in accumulation of secretions. The combination of techniques that are routinely used by physiotherapists in the $1 \mathrm{CU}$, together with adjustment of ventilator settings, can result in greater effectiveness in removing secretions. Therefore, MV can be combined with techniques that increase inspiratory flow, such as ventilator hyperinflation. This technique aims to increase alveolar ventilation and thus facilitate the cough mechanism, assisting in mucus transport. ${ }^{(9,10)}$ One way to perform ventilator hyperinflation is to increase pressure support (PS) progressively until a peak airway pressure of $40 \mathrm{cmH}_{2} \mathrm{O}$ is reached. The application of this technique has resulted in a trend toward an increase in static compliance and in the amount of secretions collected. ${ }^{(11,12)}$

The objective of the present study was to compare the efficacy of chest compression combined with a $10-\mathrm{cmH}_{2} \mathrm{O}$ increase in baseline inspiratory pressure on PS ventilation with that of aspiration alone in terms of the amount of secretions removed, hemodynamic effects, and respiratory mechanics.

\section{Methods}

This was a randomized crossover clinical trial conducted in the ICU of the Hospital de Clínicas de Porto Alegre (HCPA, Porto Alegre Hospital de Clínicas), in the city of Porto Alegre, Brazil, between May of 2008 and May of 2010. The research project was approved by the HCPA Research Ethics Committee (Protocol no. 07504/2007). Written informed consent was completed by and obtained from the legal guardian of each study participant. Randomization was performed with an online Research Randomizer, version 4.0 (Social Psychology Network, http://www. randomizer.org/), through which patients were allocated to undergo one of two techniques, and then, in the subsequent period, patients underwent the other technique.

We included patients who had been on MV for more than $48 \mathrm{~h}$, had not been diagnosed with ventilator-associated pneumonia, had a positive end-expiratory pressure $\leq 10 \mathrm{cmH}_{2} \mathrm{O}$, had an adequate respiratory drive, had undergone aspiration $2 \mathrm{~h}$ prior to the protocol being applied, and were hemodynamically stable (mean arterial pressure $\geq 60 \mathrm{cmH}_{2} 0$ ). The exclusion criteria were having contraindications to increasing positive pressure (undrained pneumothorax and hemothorax or subcutaneous emphysema), having been diagnosed with osteoporosis, having a peak pressure $>40 \mathrm{cmH}_{2} \mathrm{O}$, being a neurosurgical patient, or having declined to participate in the study.

Following inclusion, all participants were placed in the supine position, with the head of the bed elevated $30^{\circ}$, and underwent a single aspiration (number 12 tube; MarkMed Ind. e Com. Ltda, São Paulo, Brazil) with vacuum set at -40 $\mathrm{cmH}_{2} \mathrm{O}$ of pressure. All participants underwent aspiration $2 \mathrm{~h}$ prior to the application of both techniques-this procedure was performed to equate the groups in terms of secretion volume. After that period, hemodynamic and pulmonary parameters were assessed, the results of which corresponded to the patient's baseline evaluation.

Patients randomized to the control group were ventilated with $100 \% \mathrm{FiO}_{2}$ for $1 \mathrm{~min}$. Subsequently, each patient was disconnected from the ventilator and underwent aspiration for $15 \mathrm{~s}$, three times. The secretion collected was stored in a collection 
vial (Intermedical ${ }^{\circledR}$; Intermedical-Setmed, São Paulo, Brazil). Hemodynamic and pulmonary parameters were reassessed for variations $1 \mathrm{~min}$ after the aspirations, characterizing the control group.

When patients were randomized to the intervention group, they equally underwent aspiration $2 \mathrm{~h}$ prior to the procedure, in accordance with the previously described sequence. They were placed in the supine position and received chest compression combined with a $10-\mathrm{cmH}_{2} \mathrm{O}$ increase in baseline inspiratory pressure on PS ventilation. Subsequently, they underwent aspiration, and secretion was collected in the same way as for the control group patients. Hemodynamic and pulmonary parameters were reassessed $1 \mathrm{~min}$ after the technique was applied, and the results were recorded on a data collection sheet. The secretions collected were then weighed in the same way as for the control group, and weight values were recorded on a data collection sheet.

The secretions collected were weighed on a Cubis $^{\varpi}$ scale (Sartorius, Bohemia, NY, USA) in the HCPA Microbiology Laboratory. All measurements were performed by a blinded collaborator who was not part of the study team, and weight values were recorded on a data collection sheet.

We assessed hemodynamic parameters, such as $\mathrm{HR}, \mathrm{RR}$, mean arterial pressure, and $\mathrm{SpO}_{2}$ (IntelliVue MP60 monitor; Philips Medizin Systeme Böblingen $\mathrm{GmbH}$, Böblingen, Germany). Respiratory assessment involved measuring peak inspiratory pressure, expiratory tidal volume $\left(\mathrm{V}_{\text {Texp }}\right)$, and dynamic compliance (Cdyn), and these parameters were assessed prior to and after the techniques were applied. Delta values were defined as the difference between baseline and post-treatment values.

The sample size required to obtain a difference of $0.7 \pm 1.0 \mathrm{~g}$ of secretion collected or more between the groups for a $p$ value $<0.05$ and a study power of $80 \%$ was calculated to be 32 patients. We used the Statistical Package for the Social Sciences, version 18.0 (SPSS Inc., Chicago, IL, USA). Quantitative data are expressed as mean and standard deviation, whereas categorical data are expressed as absolute and relative frequencies. The groups were compared with the t-test for paired and independent samples and by using the general linear model analysis of variance for variables with normal distribution (as confirmed by the Kolmogorov-Smirnov test). The Wilcoxon test was used for variables with nonparametric distribution, whereas the chi-square test and Fisher's exact test were used for categorical variables.

\section{Results}

Between May of 2008 and May of 2010, 34 individuals were included in the study. There was a predominance of male patients, the mean age of the patients was $64.2 \pm 14.6$ years, and the most common pathology was sepsis (in (41.2\%). The other characteristics of the sample are shown in Table 1.

Assessment of variations in $\mathrm{HR}$ revealed that, in comparison with the control group, the intervention group showed an increase in HR after the intervention. However, this increase was not clinically relevant. Assessment of variations in RR revealed no significant differences between the groups. In contrast, assessment of variations in $\mathrm{V}_{\text {Texp }}$ revealed that the intervention group showed a significant increase in $\mathrm{V}_{\text {Texp }}$ after chest compression combined with hyperinflation, and the same was true for the assessment of variations in Cdyn, i.e., the intervention group showed a significant increase in Cdyn when compared with the control group. Assessment of the other parameters analyzed revealed no significant differences between the groups (Table 2).

When the mean amount of secretions collected was evaluated, we found that, in comparison with the control group, the intervention group showed a significant increase in the amount of secretions collected ( $p=0.004$; Figure 1$)$.

Table $\mathbf{1}$ - Clinical characteristics of the sample of 34 study participants. ${ }^{a}$

\begin{tabular}{lc}
\hline \multicolumn{1}{c}{ Variable } & Result \\
\hline Age, years & $64.2 \pm 14.6$ \\
APACHE 11, score & $25.5 \pm 6.6$ \\
Female gender & $15(44.1)$ \\
Duration of MV, days & $8.2 \pm 4.9$ \\
Pathology & \\
$\quad$ COPD & $7(20.6)$ \\
Bronchopneumonia & $9(25.6)$ \\
Congestive heart failure & $6(17.6)$ \\
Stroke & $8(23.5)$ \\
Sepsis & $14(41.2)$ \\
Others & $18(52.9)$ \\
\hline
\end{tabular}

APACHE 11: Acute Physiology and Chronic Health Evaluation 11; MV: mechanical ventilation; and Others: immunosuppression, AIDS, or neoplasms. $\mathrm{n} \pm \mathrm{SD}$ or $\mathrm{n}(\%)$. 


\section{Discussion}

In the present study, we found that the use of chest compression combined with an increase in PS caused an increase in the amount of secretions collected. In addition, it caused significant increases in $\mathrm{V}_{\text {Texp }}$ and Cdyn.

Some authors have shown that hyperinflation techniques can prevent lung collapse, reexpand areas of atelectasis, improve oxygenation and lung compliance, and increase the movement of secretions from small to central airways. . $^{(1,7,12-14)}$ This is due to the increase in tidal volume caused by hyperinflation, which expands the normal alveoli and thus, through the mechanism of interdependence, ultimately reexpands the collapsed alveoli. ${ }^{(15)}$

We showed that chest compression combined with an increase in PS increases the amount of secretions collected, which was similarly reported by lemes et al., who, in a randomized crossover study, found a trend toward an increase in the amount of secretions collected after hyperinflation, with increases in PS, in patients on MV ${ }^{(8)}$ In contrast, Unoki et al. showed that, in comparison with tracheal aspiration, chest compression alone resulted in no increases in the amount of secretions collected. ${ }^{(16)}$ It is possible that chest compression has greater effectiveness when combined with strategies of increasing tidal volume in patients on MV.

The fact that there was a significant increase in $V_{\text {Texp }}$ in the intervention group (i.e., those who received chest compression combined with an increase in PS) as compared with the control group is an expected finding, because it is known that increases in inspiratory pressures cause increases in lung volumes. In addition, the increase in peak inspiratory flow caused by hyperinflation can assist in moving secretions from smaller to larger airways, assisting the mucociliary mechanism, reducing airway resistance, and thus contributing to an increase in lung volumes. ${ }^{17-19)}$

Likewise, there was a significant increase in Cdyn in the intervention group as compared with the control group. This result corroborates the findings of Berney et al., who reported a significant increase in lung compliance after ventilator hyperinflation. ${ }^{\left({ }^{9}\right)}$ Savian et al. presented similar findings, attributing the increase in lung compliance to the fact that hyperinflation leads to better airflow distribution, resulting in re-expansion of collapsed lung units. ${ }^{(7)}$

One alternative to ventilator hyperinflation accomplished by increasing PS is manual

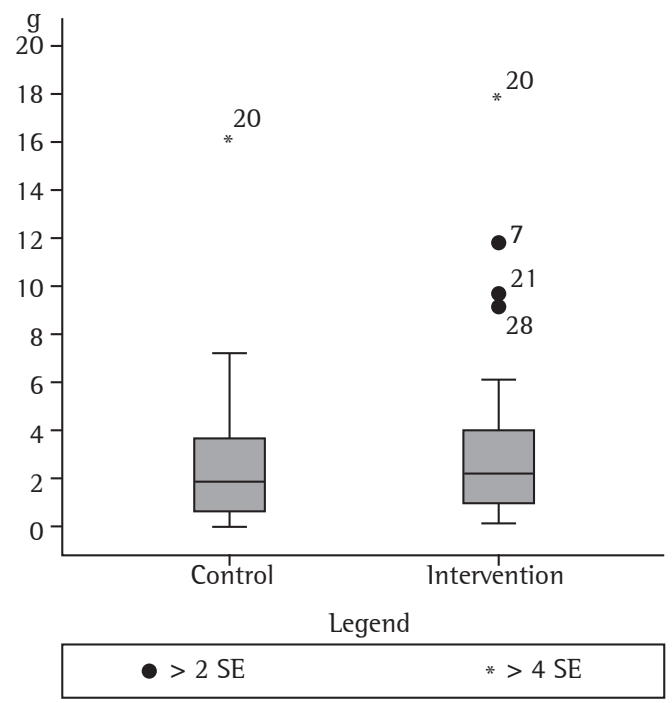

Figure 1 - Amount of secretion collected in the control and intervention groups, in median \pm standard error (SE). $p=0.004$.

Table 2 - Comparison of the variation in hemodynamic and pulmonary parameters in the groups studied.

\begin{tabular}{|c|c|c|c|c|c|c|c|}
\hline \multirow[t]{2}{*}{ Parameter } & \multicolumn{3}{|c|}{ Control group } & \multicolumn{3}{|c|}{ Intervention group } & \multirow[t]{2}{*}{$\mathrm{p}$} \\
\hline & Baseline & $\begin{array}{c}\text { Post- } \\
\text { treatment }\end{array}$ & $\Delta$ & Baseline & $\begin{array}{c}\text { Post- } \\
\text { treatment }\end{array}$ & $\Delta$ & \\
\hline HR, bpm & $97.4 \pm 22.6$ & $90.5 \pm 23.0$ & $-6.9 \pm 7.8$ & $91.6 \pm 20.6$ & $95.9 \pm 19.7$ & $4.3 \pm 9.5$ & 0.001 \\
\hline $\mathrm{RR}$, breaths/min & $20.8 \pm 5.2$ & $21.6 \pm 5.1$ & $0.7 \pm 4.5$ & $22.1 \pm 6.2$ & $22.2 \pm 5.3$ & $0.1 \pm 5.6$ & 0.592 \\
\hline MAP, $\mathrm{mmHg}$ & $90.6 \pm 20.1$ & $86.8 \pm 18.9$ & $-3.8 \pm 11.4$ & $93.2 \pm 18.8$ & $91 \pm 17.7$ & $-2.2 \pm 11.6$ & 0.515 \\
\hline $\mathrm{PIP}, \mathrm{cmH}_{2} \mathrm{O}$ & $20.7 \pm 4.1$ & $20.5 \pm 3.6$ & $-0.2 \pm 1.2$ & $20.9 \pm 4.1$ & $21.2 \pm 4.5$ & $0.3 \pm 0.9$ & 0.066 \\
\hline Cdyn, $\mathrm{cmH}_{2} \mathrm{O}$ & $34 \pm 10.3$ & $34.1 \pm 10.7$ & $0.1 \pm 4.9$ & $31.9 \pm 9.2$ & $34.8 \pm 10.2$ & $2.9 \pm 4.5$ & 0.018 \\
\hline $\mathrm{V}_{\text {Texp }}, \mathrm{mL}$ & $478 \pm 147$ & $496 \pm 121$ & $16 \pm 69$ & $465 \pm 88$ & $521 \pm 120$ & $56 \pm 69$ & 0.005 \\
\hline $\mathrm{SpO}_{2}, \%$ & $97.4 \pm 2.3$ & $96.8 \pm 3.1$ & $-0.5 \pm 2.1$ & $96.9 \pm 2.5$ & $96.9 \pm 3.0$ & $0.0 \pm 2.0$ & 0.170 \\
\hline
\end{tabular}

MAP: mean arterial pressure; PIP: peak inspiratory pressure; $\mathrm{V}_{\text {Texp }}$ : expiratory tidal volume; Cdyn: dynamic compliance. ${ }^{a}$ Values expressed as mean \pm SD. 
hyperinflation, which has the same therapeutic goals, with a manual resuscitation bag. ${ }^{(20)}$ Comparison of the two techniques reveals similar results in terms of secretion volume, improvement in respiratory mechanics, and hemodynamic stability. ${ }^{(21,22)}$ However, ventilator hyperinflation has a significant advantage in that it enables monitoring of the pressures, volumes, and flows used during its performance, thereby allowing fine tuning of the technique. ${ }^{(23)}$ Another important factor is evident in the study by Ortiz et al., who evaluated the efficacy of manual hyperinflation in a lung model and showed that, although the technique yields safe values of alveolar pressure, it may not promote secretion removal because peak inspiratory flow exceeds peak expiratory flow. ${ }^{(24)}$

We conclude that, in comparison with aspiration alone, chest compression combined with an increase in PS significantly increased the amount of secretions collected. In addition, it significantly increased $\mathrm{V}_{\text {Texp }}$ and Cdyn.

\section{References}

1. Ciesla ND. Chest physical therapy for patients in the intensive care unit. Phys Ther. 1996;76(6):609-25. PMid:8650276

2. Jerre G, Silva Tde J, Beraldo MA, Gastaldi A, Kondo $\mathrm{C}$, Leme F, et al. Physiotherapy on the mechanically ventilated patients. [Article in Portuguese] J Bras Pneumol. 2007;33 Suppl 2S S142-50. http://dx.doi.org/10.1590/ S1806-37132007000800010 PMid:18026673

3. Amato MB, Carvalho CR, Isola A, Vieira S, Rotman V, Moock M, et al. Mechanical ventilation in Acute Lung Injury (ALI)/Acute Respiratory Discomfort Syndrome (ARDS). [Article in Portuguese] J Bras Pneumol. 2007;33 Suppl 2S S119-27. http://dx.doi.org/10.1590/S180637132007000800007 PMid:18026670

4. França EE, Ferrari F, Fernandes P, Cavalcanti R, Duarte A, Martinez BP, et al. Physical therapy in critically ill adult patients: recommendations from the Brazilian Association of Intensive Care Medicine Department of Physical Therapy. Rev Bras Ter Intensiva. 2012;24(1):6-22. http://dx.doi.org/10.1590/S0103-507X2012000100003 PMid:23917708

5. Ntoumenopoulos G, Presneill JJ, McElholum M, Cade JF. Chest physiotherapy for the prevention of ventilator-associated pneumonia. Intensive Care Med. 2002;28(7):850-6. http://dx.doi.org/10.1007/s00134002-1342-2 PMid:12122521

6. McCarren B, Alison JA, Herbert RD. Manual vibration increases expiratory flow rate via increased intrapleural pressure in healthy adults: an experimental study. Aust J Physiother. 2006;52(4):267-71. http://dx.doi.org/10.1016/ S0004-9514(06)70006-X

7. Savian C, Paratz J, Davies A. Comparison of the effectiveness of manual and ventilator hyperinflation at different levels of positive end-expiratory pressure in artificially ventilated and intubated intensive care patients. Heart Lung. 2006;35(5):334-41. http://dx.doi. org/10.1016/j.hrtlng.2006.02.003 PMid:16963365

8. Lemes DA, Zin WA, Guimaraes FS. Hyperinflation using pressure support ventilation improves secretion clearance and respiratory mechanics in ventilated patients with pulmonary infection: a randomised crossover trial. Aust J Physiother. 2009;55(4):249-54. http://dx.doi.org/10.1016/ S0004-9514(09)70004-2

9. Berney S, Denehy L. A comparison of the effects of manual and ventilator hyperinflation on static lung compliance and sputum production in intubated and ventilated intensive care patients. Physiother Res Int. 2002;7(2):100-8. http://dx.doi.org/10.1002/pri.246

10. Lemes DA, Guimarães FS. The use of hyperinflation as a physical therapy resource in intensive care unit. [Article in Portuguese] Rev Bras Ter Intensiva. 2007;19(2):221-5. http://dx.doi.org/10.1590/S0103-507X2007000200014

11. Branson R. Secretion management in the mechanically ventilated patient. Respir Care. 2007;52(10):1328-42; discussion 1342-7. PMid:17894902

12. Singer M, Vermaat J, Hall G, Latter G, Patel M. Hemodynamic effects of manual hyperinflation in critically ill mechanically ventilated patients. Chest. 1994;106(4):1182-7. http://dx.doi.org/10.1378/ chest.106.4.1182 PMid:7924493

13. Hodgson C, Carroll S, Denehy L. A survey of manual hyperinflation in Australian hospitals. Aust J Physiother. 1999;45(3):185-93. PMid:11676766

14. Denehy L. The use of manual hyperinflation in airway clearance. Eur Respir J. 1999;14(4):958-65. http://dx.doi. org/10.1034/j.1399-3003.1999.14d38.x PMid:10573249

15. Stiller K. Physiotherapy in intensive care: towards an evidence-based practice. Chest. 2000;118(6):1801-13. http://dx.doi.org/10.1378/chest.118.6.1801 PMid:11115476

16. Unoki T, Kawasaki Y, Mizutani T, Fujino Y, Yanagisawa Y, lshimatsu S, et al. Effects of expiratory rib-cage compression on oxygenation, ventilation, and airway-secretion removal in patients receiving mechanical ventilation. Respir Care. 2005;50(11):1430-7. PMid:16253149

17. Choi JS, Jones AY. Effects of manual hyperinflation and suctioning in respiratory mechanics in mechanically ventilated patients with ventilator-associated pneumonia. Aust J Physiother. 2005;51(1):25-30. http://dx.doi. org/10.1016/S0004-9514(05)70050-7

18. Van der Schans CP. Bronchial mucus transport. Respir Care. 2007;52(9):1150-6; discussion 1156-8. PMid:17716383

19. Santos LJ, Blattner CN, Micol CA, Pinto FA, Renon A, Pletsch R. Effects of manual hyperinflation maneuver associated with positive end expiratory pressure in patients within coronary artery bypass grafting. [Article in Portuguese] Rev Bras Ter Intensiva. 2010;22(1):40-6.

20. Berti JS, Tonon E, Ronchi CF, Berti HW, Stefano LM, Gut $\mathrm{AL}$, et al. Manual hyperinflation combined with expiratory rib cage compression for reduction of length of ICU stay in critically ill patients on mechanical ventilation. J Bras Pneumol. 2012;38(4):477-86. http://dx.doi.org/10.1590/ S1806-37132012000400010 PMid:22964932

21. Dennis D, Jacob W, Budgeon C. Ventilator versus manual hyperinflation in clearing sputum in ventilated intensive care unit patients. Anaesth Intensive Care. 2012;40(1):142-9. PMid:22313075

22. Savian C, Paratz J, Davies A. Comparison of the effectiveness of manual and ventilator hyperinflation at different levels of positive end-expiratory pressure in artificially ventilated and intubated intensive care 
patients. Heart Lung. 2006;35(5):334-41. http://dx.doi. org/10.1016/j.hrtlng.2006.02.003 PMid:16963365

23. Berney S, Denehy L, Pretto J. Head-down tilt and manual hyperinflation enhance sputum clearance in patients who are intubated and ventilated. Aust J Physiother. 2004;50(1):9-14. PMid:14987187
24. Ortiz Tde A, Forti G, Volpe MS, Carvalho CR, Amato MB, Tucci MR. Experimental study on the efficiency and safety of the manual hyperinflation maneuver as a secretion clearance technique. J Bras Pneumol. 2013;39(2):20513. PMid:23670506

\section{About the authors}

Wagner da Silva Naue

Physiotherapist. Adult 1CU, Hospital de Clínicas de Porto Alegre - HCPA, Porto Alegre Hospital de Clínicas - Porto Alegre, Brazil.

\section{Luiz Alberto Forgiarini Junior}

Professor of Physiotherapy. Methodist University Center, Porto Alegre Institute, Porto Alegre, Brazil.

\section{Alexandre Simões Dias}

Professor. Graduate Program in Human Movement Sciences and Respiratory Sciences, Federal University of Rio Grande do Sul, Porto Alegre, Brazil.

\section{Silvia Regina Rios Vieira}

Professor. Federal University of Rio Grande do Sul School of Medicine; and Head. Department of Intensive Care, Hospital de Clínicas de Porto Alegre - HCPA, Porto Alegre Hospital de Clínicas - Porto Alegre, Brazil. 